Thorax (1973), 28, 293.

\title{
Viability of fresh mitral homograft valves
}

\author{
NAWAL AL-JANABI and DONALD N. ROSS \\ Department of Surgery, National Heart Hospital, and Institute of Cardiology, London
}

The present study was undertaken to measure and compare the viability of the mitral leaflet, chordae, and papillary muscle. The viability of the valves was assessed by autoradiography at regular intervals after sterilization and preservation in antibiotics and nutrient medium.

The results showed different rates of decline in viability of the leaflet, muscle, and chordae of the mitral valves. Slightly more than $70 \%$ of the leaflet fibroblasts took up thymidine during the first 24 hours of storage. This is compared with $68 \%$ of papillary muscle fibroblasts and $40 \%$ of chordae fibroblasts. Viability of the chordae decreased rapidly and became pronounced at four weeks. One week is the maximum time for storage of mitral valves if it is desirable to preserve living cells in the chordae.

Cadaveric mitral homograft valves had been used (by D.N.R.) as a replacement of the mitral valve. Although the structural integrity of the leaflet and the papillary muscle did not deteriorate after several months of implantation in patients, the chordae were liable to deteriorate and rupture. This may be related in some measure to the fact that the chordae lack living cells. As it has become clear that the long-term function of aortic homograft valves relates to the methods of sterilization and storage used (Hudson, 1966 ; Smith, 1967 ; Davies et al., 1968) storage in antibiotic and nutrient media could be advantageous for the mitral valves also.

This paper records an attempt to measure and compare the viability of the mitral leaflet, chordae, and papillary muscle using an autoradiographic technique already described (Al-Janabi, GonzalezLavin, Neirotti, and Ross, 1972).

\section{MATERIALS AND METHODS}

Thirty-three mitral valves complete with chordae and papillary muscles were collected under unsterile conditions within 48 hours of death. After dissection the valves were placed in nutrient medium (Morgan, Morton, and Parker, 1950) to which the National Heart Hospital formula antibiotics (Lockey, Al-Janabi, Gonzalez-Lavin, and Ross, 1972) had been added (Table). Samples of the muscle, leaflet, and chordae were taken at intervals ranging from 24 hours to 12 weeks after the valves had been placed in the nutrient-antibiotic solution. Each sample was divided into two pieces, one for autoradiography and the other for routine histology.

Tritiated-thymidine was added to one specimen and autoradiography was carried out (Al-Janabi et al., 1972). The routine histological specimen was fixed, sectioned, and stained by four methods-Verhoeff's stain, haematoxylin and eosin, Mallory, and toluidine blue - to document the changes that had occurred during the period of storage.

T A B L E

PRESENT NUTRIENT-ANTIBIOTIC SOLUTION

\begin{tabular}{lr}
\hline $\begin{array}{l}\text { Nutrient medium: } \\
\text { Medium 199 (10X) with no sodium bicarbonate }\end{array}$ & $10 \mathrm{ml}$ \\
Preheated calf serum No. 11 & $8 \mathrm{ml}$ \\
$4.4 \%$ sodium bicarbonate & $5 \mathrm{ml}$ \\
Sterile distilled water & $77 \mathrm{ml}$ \\
& \\
Antibiotic formula (Lockey et al., 1972): & $4 \mathrm{mg} / \mathrm{ml}$ \\
Gentamicin & $10 \mathrm{mg} / \mathrm{ml}$ \\
Methicillin & $6 \mathrm{mg} / \mathrm{ml}$ \\
Erythromycin-Lactobinate & $2500 \mathrm{units} / \mathrm{ml}$ \\
\hline
\end{tabular}

1Burroughs-Wellcome and Co., Dartford, Kent

RESULTS

Autoradiography showed that the viability of the leaflet, muscle, and chordae of the mitral valve had different rates of decline, as judged by the percentage of viable cells (Figure). Slightly more than $70 \%$ of the leaflet fibroblasts took up thymidine during the first 24 hours of storage. This is compared with $68 \%$ of papillary muscle fibroblasts and $40 \%$ of chordae fibroblasts. Leaflet tissue showed a steady decline in thymidine uptake and hence viability, which became pronounced after eight weeks. Papillary muscle viability showed a steady decline during the first $\mathbf{7 2}$ hours and this accelerated after two weeks of storage. Chordae viability showed a slower rate of decline.

HISTOLOGY Histological examination of the leaflet and papillary muscle showed a normal structure even after 12 weeks of preservation in an antibiotic- 
nutrient medium. The chordae, however, showed fairly normal structure after one week of preservation, but after four weeks there was an alteration of the disposition of the collagen fibres.

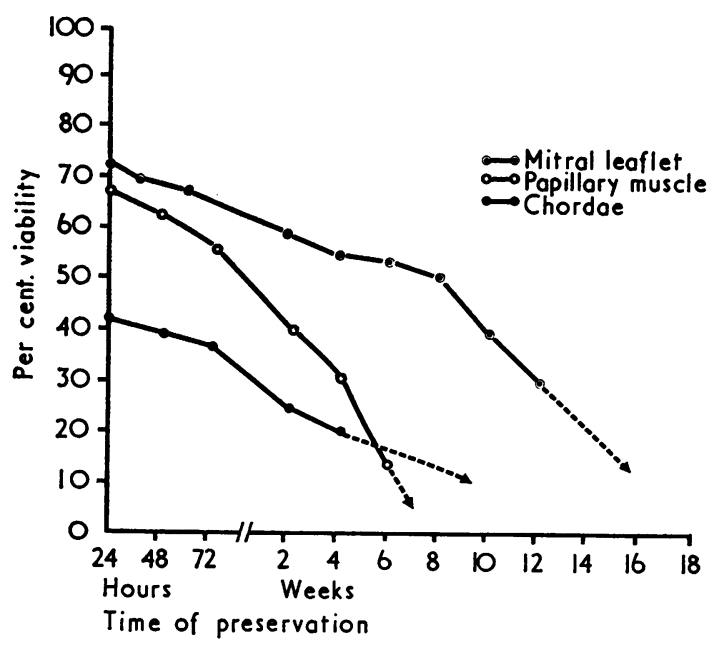

FIGURE. Shows the viability of the mitral valves stored in antibiotics and nutrient medium.

\section{DISCUSSION}

Cell viability and structural integrity appear to be the important parameters by which to judge the prospects for long-term valvular function. We have attempted to assess cell viability by measuring and comparing the division index of the fibroblasts in the leaflet, chordae, and papillary muscles of the mitral valves. This was accomplished by autoradiography using tritiated thymidine. Thymidine is a precursor of deoxyribonucleic acid (DNA) and, when labelled with tritium, the utilization of thymidine in those cells about to undergo cell division can be traced (Fitzgerald, Simmel, Weinstein, and Martin, 1953; Taylor, 1965). As this pyrimidine base is incorporated into DNA of chromosomes during their cell division, the nuclei of those cells and their daughter cells will then be labelled while cells which are in other stages of interphase or not dividing at all remain unlabelled. The number of labelled cells is compared with the total number of cells and is then related to time (Baserga and Malamud, 1969).

This technique has permitted a quantitative $\frac{\bar{O}}{\bar{c}}$ analysis of the percentage of presumed viable cells $\vec{\nabla}$ remaining in the valve and capable of cell division. $\varrho$ The study we have undertaken indicates that the $\%$ percentage of labelled cells after 24 hours' storage $\overrightarrow{0}$ is higher in the leaflet than in the muscle or the chordae. These results show that the viability of $\vec{\omega}$ the chordae decreases rapidly and becomes pronounced at four weeks. These results coincide with $\times$ the histology. Whether it is possible after two $\infty$ weeks' preservation for the valve cells to regain $\omega$ their structural and functional integrity when $C$ inserted into a patient is not known. Our experimental work indicates that one week is the maximum time for storage of mitral valves if it is desirable to preserve living cells in the chordae.

We wish to thank Mr. R. Parker for consistent co- $\vec{\theta}$

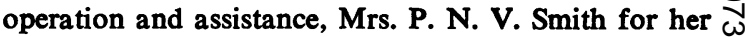
work in the preparation of the homografts, and Miss C. Grimes for technical assistance.

\section{REFERENCES}

Al-Janabi, N., Gonzalez-Lavin, L., Neirotti, R., and Ross, D. N. (1972). Viability of fresh aortic valve homografts. A quantitative assessment. Thorax, 27, 83.

Baserga, R., and Malamud, D. (1969). Modern methods in experimental pathology. Autoradiography: Techniques and Application. Hoeber, New York.

Davies, H., Missen, G. A. K., Blandford, G., Roberts, C. I., 음 Lessof, M. H., and Ross, D. N. (1968). Homograft replacement of the aortic valve. A clinical and pathologic study. Amer.J. Cardiol., 22, 195.

Fitzgerald, P. J., Simmel, E., Weinstein, J., and Martin, C. (1953). Radioautography: Theory, technic and applications. Lab. Invest., 2, 181.

Hudson, R. E. B. (1966). Pathology of the human aortic 음 valve homograft. Brit. Heart J., 28, 291.

Lockey, E., Al-Janabi, N., Gonzalez-Lavin, L., and Ross, D. N. (1972). A method of sterilizing and preserving fresh allograft heart valves. Thorax, 27, 398.

Morgan, J. F., Morton, H. J., and Parker, R. C. (1950). Nutrition of animal cells in tissue culture. 1. Initial $\mathrm{N}$ studies on a synthetic medium. Proc. Soc. exp. Biol., N N.Y., 73, 1.

Smith, J. C. (1967). Pathology of human aortic valve homografts. Thorax, 22, 114.

Taylor, J. H. (1965). Distribution of tritium-labeled DNA among chromosomes during meiosis. J. Cell Biol., 25, no. 2 , pt. 2 (May suppl.), 57. 